\title{
III: People I Met, Thoughts I Had
}

\section{Viviane Saleh-Hanna}

$\mathrm{O}$ ne of the most shocking realizations I had while living and working in Nigeria was that colonial rule has not been abolished from Africa. While the governmental and visibly official colonial structures have been removed, I quickly came to the conclusion that it is naïve to believe that this has resulted in the elimination of Western colonial rule of the African states they have defined. The invisible colonial structures that still exist have a new language, a new "political" form and continue to implement a new method of social and economic control over the country while maintaining the same old colonial outcomes: the exploitation of Africa by a handful of Western nations continues at so many levels. It is not a "neo"-colonial condition - it is a colonial condition devoid of white men in official positions of governmental power.

The Penal System, a system that was not made by or for the West African society, is still being imposed upon Nigeria. Its inefficiency reflects the inefficiency that rules the country's general state: the people get caught in a grinding machine that destroys all it touches. I have come to see the penal system as a tool through which colonial structures are implemented among those the national and international corporations cannot "employ." The more time I spent working with Nigerian prisoners, and the more I was confronted with police brutality openly occurring on the streets of Lagos, the more convinced I became of the fact that the penal system in Nigeria is the most visible symbol of continued colonial occupation in the Nigerian mental state and Nigerian governmental structures.

\section{A Broken Man Shares his Story}

On April 30, 2001, late in the afternoon, an elderly man named Felix who had just been released from Kirikiri Maximum Security Prison that morning came to the PRAWA office. He told me that he had just come from the courthouse where he was informed, after nine years of awaiting trial, that his case was "thrown out of court" three years ago. "No one told you?" the judge asked him. He was free to go for three years and no one noticed. Upon hearing what he called the "bittersweet" truth, he was released. The prisons and the courts did not give him enough money to pay for transportation off 
the prison grounds. He walked all day and eventually found himself at the PRAWA office. He was seeking assistance. Felix explained that too many people released from prison after many years behind bars, are not given any money for transportation home and, often, have to steal to get themselves home to their families or friends.

The majority of ex-prisoners often have no home to go to: the stigma attached to imprisonment is so strong, it does not differentiate between awaiting trial or convicted prisoners. The viewpoint I have heard most often expressed by Nigerians about prison held these basic tenets: people expressed awareness of the problems that push people to "break the law" or that expose people to police brutality and wrongful imprisonment, but at the same time, they see prison as a mysterious and scary place, so despite the reasons that lead a person there, upon release, that person too becomes mysterious and scary. Many ex-prisoners end up living on the streets and eventually go back to prison. Felix had lost all contact with his family and had nowhere to go. My office did have a home for ex-prisoners to use as a transition point after prison, but the rooms were never enough for the number of people who needed them. We did have a room for him at the time, and he stayed there for the entire time I was in Nigeria. I am not sure what will happen to him if that home can no longer be sustained by PRAWA. ${ }^{24}$

\section{The Penal System Questions Itself?}

\section{Awaiting Trial Prisoners}

As noted before, the majority of prisoners in Nigeria are awaiting trial. I had the opportunity to discuss this specific issue during several DFID ${ }^{25}$ funded "access to justice" workshops held in July 2001 in Makurdi, Benue State. These workshops were attended by the police force, the prison service, the Nigerian Bar association, judges, magistrates, and community members. Upon attempting to find the "root" cause of the disproportionately high

24 As far as I know, official funding for that home was not available. It was sustained through various donations and efforts by the PRAWA staff reaching out to the community for help.

25 Department for International Development: the development and foreign aids branch of the British Government. 
prisoner population that had not been taken to court for years, it became clear that a criminal justice system with a weak infrastructure does not provide shelter from the bureaucratic administrative legitimizations of inhumanity that take place in Western based criminal justice systems that function within more rigid and defined infrastructures. Blame for the large ATM population in Nigeria was passed from one sector to the next. The bureaucratic reality set in as it became clear that the "root" cause of this problem is not linked to a specific segment of the criminal justice system in Nigeria, but was the result of the collective efforts of all branches involved. Unfortunately, within the context of bureaucracy, the distribution of responsibility creates a shield whereby direct responsibility for shortcomings gets distributed into an ambiguous, insoluble, "unfortunate" situation.

The magistrates and lawyers who work in the courts openly blamed the police for arresting too many people indiscriminately while at the same time pointing fingers at the government's refusal to provide them with proper resources (technological recording devices, non-payment of salaries, etc.) to deal with such high numbers. The prison guards also lay blame on the police for such misconduct while pointing fingers at the court for its inability to "speed up" the entire process. The police pointed fingers at the lawyers and the court officials who are not working efficiently enough and thus causing a backlog in the penal process that results in a large awaiting trial prison population. A large number of the prison staff who participated in these "access to justice workshops" openly stated that they felt that Nigerian prisons are the "dumping grounds for the Nigerian penal system's inefficiency and injustice." The police force staff claimed that Nigerian society has gotten so violent that they have no choice but to arrest as many people as they do. The courts stated that they are the scapegoats of inefficient structures and inappropriate police actions. The community continues to suffer at great expense and the penal structure continues to expose itself through the constant failures and degradations it imposes upon all those whose lives it touches.

\section{Fear and Social Control}

The "awaiting trial situation" in Nigeria puts people in fear of the police, for those who are not "well connected" or who do not have money, it is an everyday reality that they can be picked up by the police and they can 
disappear in prison for years, or forever. Many prisoners gave me notes to pass on to their families; many prisoners had been missing for years and their families presumed they had died. The amount of power the police gather through these imposed fears are immense. It puts the penal system in a position of power that is not only unquestionable to the average citizen, it is almost undeniable to the homeless population in Nigeria. Because they have no home to sleep in at night, they are easier targets for the police. This level of power, so openly displayed against the poorest people in the country, is publicly acknowledged among the majority of the citizens of the country. In Nigeria, the connections between poverty and crime are clear; so are the connections between poverty and vulnerability to penal brutality.

\section{Prisons}

\section{Health in Prison: A Religious Experience}

Inside Kirikiri Medium Security Prison, the convicted prisoners' cell blocks hold up to 20 prisoners while the awaiting trial prisoners' cell blocks (they are approximately the same size) hold 77 . These blocks consist of one cement room with small windows on either side of the wall. In other parts of Nigeria, such windows do not exist and thus ventilation is much worse than it is in the dilapidated conditions in Kirikiri Medium Security Prison. The awaiting trial prisoners do not have beds or mats to sleep on, and the conditions are so congested that they must take turns to sleep on the floor. On all occasions I have had to visit the health clinic in Kirikiri Medium Security Prison, I have seen an overwhelming majority of the awaiting trial prisoners seeking medical attention. They are made to sit on the ground outside the clinic as they wait for access to health care. Those prisoners who do not come in time for prayers are not allowed to visit the clinic that day. I have witnessed on several occasions prison officers "herding" about fifty ill prisoners with a stick and beating those who did not move fast enough; the majority of the time, I saw them beating prisoners on the head. I have heard those prisoners seeking medical attention being made to shout and scream their "amens and hallelujahs" prior to seeing the nurses. It is generally those prisoners who look like walking skeletons, half naked sitting on the ground, who are made to sing, clap, and chant as they wait to be seen by the nurse.

Inside the clinic, where I spent an entire day (September 7, 2001) I noticed that the medical staff does very little of the assessment of sick 
prisoners. There are several convicted prisoners who are made to check if the ailments exist (if there are complaints of visible illnesses) and one medical staff nurse who, upon order from the Matron (the Head Nurse) gave a shot of painkillers to the prisoner who is made to drop his pants in front of everybody. Any prisoner who showed any fear of the needle or hesitated to take the medication, or was ashamed to "drop his pants," was ridiculed and threatened by the prison's medical guards.

Because a proper financial budget does not exist for awaiting trial prisoners, there are no proper provisions for their imprisonment. Convicted prisoners wear blue uniforms; awaiting trial prisoners are made to wear the clothes they were arrested in. The majority of them no longer fit those clothes due to the overwhelming weight loss and malnutrition they suffer during their imprisonment. Upon discussing the issue of food with some of the convicted prisoners, they explained to me, in form of a letter how "the system works." They explained that the Nigerian Prison Service hires a contractor who supplies the food to the prison. Before supplying the food, the contractor takes his/her "cut" and passes the food onto the prison headquarters in Abuja, the federal state capital. In Abuja, the prison officials take their "cut" and pass the food down to each of the state controllers of prison, who in turn take their "cut" and pass the food down to the controllers of each prison, who of course take their "cut" and pass the food down to the yard where the chief of the yard takes his "cut" and passes the food down to the kitchen where the guards in charge there help themselves to their "cut" and pass it down to the convicted prisoners who cook it and who admitted to serving themselves and their friends bigger portions. What is left of the food then gets distributed to the rest of the prisoners in the yard, first the convicted and then to the awaiting trial prisoners. Some prisoners also explained (in form of a letter they wrote for me) that during a prison visit by Obasanjo's ${ }^{26}$ Special Assistant on Prisons to assess living conditions in Nigeria's prison system, prison officers brought in twelve extra bags of garri (one of the staple foods in Nigeria) for him to see as available food for prisoners and after he left, took back thirteen bags. These accounts and stories helped me better understand how prisoners in Nigeria have come to experience such malnourishment. On an ironic note, prisoners have pointed 
out that the car that is used to move dead bodies ${ }^{27}$ from the prison yard to the mortuary is also the same car that prison officers use to move the food from the prison yard to their homes.

In addition to malnutrition, there are other factors that contribute to the poor health conditions of prisoners. In the majority of the prisons, there is no clean water to drink. Wells are dug into the ground and are not properly maintained. Upon looking inside the wells, one can often see the insects and the worms that live inside and around them. In the overwhelming majority of the prisons, those wells are the only source of water for drinking and for bathing. They are also a breeding ground for mosquitoes, among other insects, and this has created an increase in the number of prisoners who suffer from malaria. While diagnosis and treatment of malaria is cheap and readily available in Nigeria, it has been stated that untreated malaria is one of the main causes of death in Nigeria. In prison, testing and medication for malaria is not readily available and since there are very few official records outlining the cause of death for the many who die inside prison, the number of people affected is not available.

Another problem prisoners face is the lack of medicine for diseases such as tuberculosis. In Kirikiri Medium Security Prison, there were eightythree prisoners suffering from tuberculosis (TB) while I was there. These prisoners were segregated to the "tuberculosis" cell because it is a contagious and lethal disease. They are given medicine when the medicine is available (mainly through donations from churches or other charitable organizations) and when the medicine runs out, the treatment stops, until the next batch of medicine is bought or donated. This has created a group of prisoners who have developed a form of TB that is immune to medication. If released alive from prison, these people will spread a form of tuberculosis among the community that is immune to the medicine now available for curing tuberculosis. Considering the fact that tuberculosis is a highly contagious disease that is spread through sharing the same air space, the possibilities for disaster are massive.

The ironic detail among all these issues with medicine for prisoners suffering of TB is that in Lagos state, where Kirikiri Medium Security Prison is located, TB medication is free. This was one of the promises the

27 So many malnourished and half-starved prisoners die inside Nigerian prisons. 
Lagos State Governor, Mr. Tinubu, made to the people when he was elected in 1998. The loophole for receiving the medication is that proof has to be given of the fact that the patient is suffering from tuberculosis, and the administration of these tests is very expensive. The high expense for these tests (along with the minimal prison health care budget) results in prisoners being moved to the TB cell without proper testing and diagnosis of TB. Any loud coughing may result in one being moved to the TB cell. Upon entering the TB cell, most prisoners are never released back into the general population for two reasons:

- They almost never get the full dose of treatment and thus rarely recover to full health or,

- The few who do get the full dose through friends or family members who provide the medication cannot be sent back to the general cells because other prisoners fear contracting TB and do not trust the authorities to have treated infected prisoners properly before releasing them back into the general population.

Prisoners who enter the TB cells rarely leave them alive; those who get discharged during their confinement in TB cells leave the prison very sick and rarely survive due to lack of money or due to the immunity they have built to TB medication while in prison.

\section{Beatings in Prison}

While most of my knowledge of torture came from the stories I heard from prisoners, and their visible scars, there were several occasions where I witnessed beatings of prisoners by prison guards. This often took place in front of the Chief Officer's office, in the prison yard where all prisoners could see and hear exactly what was going on. Discussions and questions with the prison guards about these beatings led me to learn that they were over "prison rule infractions" and were almost always linked to drug trafficking in prison. One of the most horrific beatings I saw a prisoner get was one given by the Chief [prison guard] of the yard himself. He was "teaching" his "officers" how to beat a prisoner properly.

On a hot Wednesday afternoon, May 16, 2001, I witnessed a highly disturbing and degrading moment. It happened during a program I ran with convicted prisoners underneath a tree in the yard. Two awaiting trial 
prisoners were allegedly caught dealing drugs inside prison and the prison guards felt they had to make examples out of them. Within sight of the majority of the prisoners in the yard, they were made to kneel handcuffed, shackled, and shirtless in the burning sun for hours. They were stripped down to their underwear. The kneeling was proceeded by brutal beatings with wooden sticks and whipping with leather whips. The handcuffed and shackled men were then forced to stand up and hop from the guard's office to the "white painted doorway" leading to solitary confinement: a section in the yard that prisoners refer to as "Angola." As the prisoners were made to hop to Angola, prison guards were mimicking them, hovering around them, imitating their actions and their posture, walking as they were walking with the shackles and hopping around behind them as they hopped their way to solitary confinement. The scene was degrading, horrific, and violent on so many physical, mental, and emotional levels. This was one of several times I had witnessed prisoners being beaten by guards in Kirikiri Medium Security Prison.

I did not witness a lot of violence between prisoners. The only instance of violence among prisoners that I did come across occurred on September 10, 2001. The Chief of the yard called me into his office to show me what two mentally challenged prisoners had "done to each other." One had given the other an open head wound; the wounded one was shackled, the "assailant" looked very confused. The Chief of the yard was leading them with a stick to the clinic. The chief of the yard explained to me that they had six mentally ill prisoners and said that he was seeking funds to have them transferred to the Yaba Psychiatric hospital. Despite the beatings and the brutality I saw him inflict upon prisoners, I also witnessed him providing housing for exprisoners who did not have a home to stay at, buying clothes for those who did not have sufficient clothing for release, and he did so through his own personal donations. The contradictions in the prison system in Nigeria once again illustrated that despite the brutal structures of this violent system, there were a few times where humanity did manage to prevail. The Nigerian custom to "help thy neighbour" did override the European custom of penal dehumanization and use of violent institutions.

The beatings that I did witness inside prison generally occurred while I was running the Prisoners' Circle Program in the prison yard and I often discussed with the prisoners who were witnessing the beatings with me what can be done in this situation. I was told that going to the guards and interrupting them would result in harsher beatings for the prisoner after I 
left. I had to resort to talking to the prison guards about it after they finished, and when I was on my way out of the prison. Discussion had to be carefully worded; I did not want to put the prisoners at risk of further torture and punishment. The overwhelming response from the prison guards who did engage me in discussion was one that fell back on the penal system's crime and punishment rhetoric. Once again, the Nigeria penal system succeeded in illustrating the violent and degrading potentials that the people who work within it can reach while emphasizing the justification functions that allow and encourage this institution of violence.

Overcrowding: The Baroness Helena Kennedy's Visit to Kirikiri, Lagos On April 26, 2001, the British Baroness Helena Kennedy was in Nigeria for a visit. Part of her visit, organized by the British Council, allowed for a visit to Kirikiri prisons in Lagos. Inside the medium security prison yard, we walked through the convicted and awaiting trial sections of the prison. The awaiting trial section of the medium security prison had been "cleaned up" for her visit, yet what we saw was horrific. Inside each cell block holding over seventy prisoners each, were half-naked, skeleton-like men staring at us through the bars. Some tried to get her attention, pleading for help. The entire scene made me cringe, both at the inhumanity of the conditions and the power differentials exhibited. Most prisoners in this section of the yard rarely see people from the "outside" and thus any chance to be seen or heard represented the chance to briefly exist. Ironically, the sight of a white person elicited hope of salvation, despite the fact that the prison is a white-made institution.

The smell in this section of the yard was overwhelming. Unclean water holes were left exposed; people had been locked up for days, maybe weeks. There are no words I can find to describe the sensation. The Baroness Helena Kennedy and the British Council's executive director for West Africa were mortified by their prison visit. Upon returning home, I was informed by my Nigerian colleagues that the "foreign" visitors were both physically ill after seeing the prisons that day; and they saw the prison yard in its best, cleaned-up condition.

\section{Women and Children}

There is only one prison in Nigeria that exclusively imprisons women. It is located on Kirikiri prison grounds and imprisons, on average, 150 to 200 females. I met some prisoners who were fifteen years old and others 
who looked even younger. On average, there were between eleven and fifteen convicted women, while the rest of that prison's population were all awaiting trial. Kirikiri female prison only has female prison guards working in it and it is not as overcrowded as its neighbouring male prisons. It is also the prison that I had the hardest time gaining access to and the prison where I saw some of the most brutal forms of punishment being imposed.

Maintaining the stereotypes of how women are "expected" to behave, the majority of the punishments and the oppressive tactics involved emotional manipulations and degradations while the physical torture was "kept to a minimum." I witnessed women being made to kneel on the ground in the scorching sun for hours in the prison yard. They were being punished for being involved "romantically" with each other. I met women who were in prison with their babies: they were either pregnant upon arrest or had their children with them at the time of arrest and did not have anywhere to leave them before the police took them to prison. Some of the babies I met in this prison had never seen a man in their life. The women told me about an Amnesty International visit that included several male visitors. One of the toddlers was so confused and scared by the sight of a man she cried for hours.

The female prison in Kirikiri was the only prison in Nigeria that did not allow me to donate food directly to prisoners: I had to leave all donations with the prison guards and they "distributed it" after I left. Prisoners reported not receiving full portions of what was left for them. The level of disrespect and resistance I received from the female prison warden was so immense that I had a hard time working with the women, and thus cannot say that I confidently fully comprehend what takes place in that prison. I was able to visit the Death Row section several times. On March 1, 2001, I saw two prisoners who were severely developmentally challenged awaiting execution. One sat naked in her cell in a trance and the other knelt when she saw me and told me about her hallucinations and her fears.

Women arrested and imprisoned outside of Lagos State are held in male prisons in "compartments" built within the male prison yard for them. Upon visiting Makurdi Prison on July 25, 2001, I asked the prison guards in that prison what happens when women get sick and are in need of medical attention. The clinic is located in the male section of the prison yard. The response I got was short and simple: "Women are hygienically cleaner than men and do not need to go to the clinic to heal, they can stay in their cells and heal there." 
In addition to the lack of access to medical care, there are also situations where women become pregnant in these prisons and it was unofficially reported that these pregnancies were the result of rapes by prison guards or by male prisoners who the prison guards were "doing favours" for. This prison held twenty women, eighteen of whom were awaiting trial. Of the two who were convicted, one talked about the "insurance" system that resulted in her conviction.

After leaving Makurdi Prison, and before heading back to Lagos to further investigate the "insurance" policy, we stopped at a new model prison, built just outside the boundaries of Makurdi in Benue State. It was an eerie sight for me; this building resembled North American prisons, right down to the type of bricks used for outdoor hallways and the colour of the paint inside the "reception." Apparently a blueprint of the "modern" Western prisons had been sold to Nigeria, I am assuming along with the building supplies. I was not able to confirm if this was done through private prison industry or governmental means. I was able to confirm that the prison has not been in use, although construction is complete, due to a conflict between the building contractors and the Nigerian government. Our "tour guide," a Nigerian Prison Service officer, stated that the Nigerian government did not pay the contractor in full, so in retaliation, the contractor "kept the keys."

In Lagos, whenever I had access into Kirikiri Female prison, I inquired about the reasons for imprisonment and eventually came to learn more about the "insurance" policy as it gets implemented by the Nigerian Police Force. I consulted with several lawyers for more details and learned that if a male crime suspect cannot be located by the police during an investigation, the police arrest the first woman they find who has connections to him (mother, wife, girlfriend, daughter, niece, etc.) and proceed to take her into custody for "insurance" purposes. If the man does not "present himself to the police" within a certain period of time, the woman gets sent to prison to await trial for his crime. Many of the women I spoke to in Nigerian prisons were being held under such circumstances, some had been sentenced on "conspiracy" charges as a result of these "insurance policies." Other women I spoke to who had been imprisoned for crimes not related to the "insurance policy" were serving time for crimes (mainly drug trafficking offences) they committed for their husbands. Many spoke about the financial situations they were in and the reasons behind their "decisions" to help their husbands support their family. 